\title{
Risk of aggression and criminal behaviour among adolescents living in Alexandria Governorate, Egypt
}

\author{
I. Wahdan, ${ }^{1}$ N. El-Nimr, ${ }^{7}$ R. Kotb ${ }^{2}$ and A. Wahdan ${ }^{3}$
}

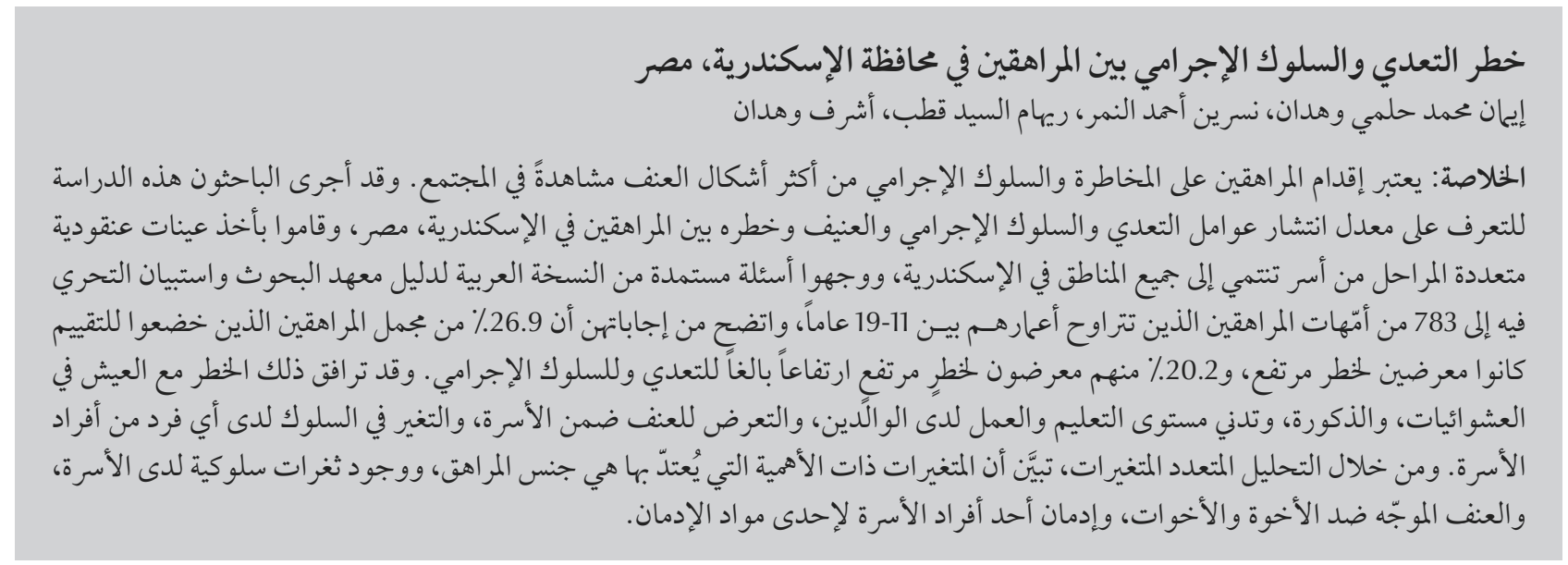

ABSTRACT Adolescent risk-taking and aggressive behaviours are among the most visible forms of violence in society. A study was carried out to identify the prevalence and risk factors for aggression, violence and criminal behaviour among adolescents in Alexandria, Egypt. Using multistage, cluster sampling of families from all health districts in Alexandria, the mothers of 783 adolescents aged 11-19 years answered an Arabic version of the Mentor Research Institute screening questionnaire. Overall $26.9 \%$ of adolescents were assessed to be at high risk and $20.2 \%$ at extremely high risk of aggression and criminal behaviour. Living in urban/slum areas, male sex, low level of parents' education/occupation, exposure to violence within the family and changes in behaviour of any family member were associated with risk of aggression/violence. In multivariate analysis, the significant independent variables were adolescents' sex, presence of behavioural changes in the family, violence against brothers and sisters and substance abuse by any family member.

Risque d'agression et de comportement criminel chez des adolescents vivant dans le gouvernorat d'Alexandrie (Égypte)

RÉSUMÉ La prise de risque chez les adolescents et les comportements agressifs sont les formes les plus visibles de la violence en société. Une étude a été menée pour identifier la prévalence et les facteurs de risque d'un comportement agressif, violent et criminel chez des adolescents à Alexandrie (Égypte). À l'aide d'un échantillonnage en grappes à plusieurs degrés de familles dans tous les districts sanitaires d'Alexandrie, les mères de 783 adolescents âgés de 11 à 19 ans ont rempli le questionnaire de dépistage du Mentor Research Institute dans sa version en langue arabe. Globalement, 26,9\% des adolescents ont été évalués comme étant à haut risque et 20,2 \% à extrêmement haut risque de comportement agressif et criminel. Le fait de vivre dans des zones urbaines/d'habitat insalubre, d'être de sexe masculin, d'avoir des parents dont le niveau d'études/professionnel est faible, d'être exposé à une forme de violence familiale et à des modifications de comportements de membres de la famille ont été des facteurs associés au risque de comportement agressif/violent. À l'analyse multivariée, le sexe de l'adolescent, la présence de changements comportementaux dans la famille, la violence envers les frères et sœurs et la toxicomanie de membres de la famille étaient des variables indépendantes importantes.

${ }^{7}$ Department of Epidemiology; ${ }^{2}$ Primary Health Care, Department of Tropical Health; ${ }^{3}$ Department of Biostatistics, High Institute of Public Health, University of Alexandria, Alexandria, Egypt (Correspondence to l. Wahdan: imanwahdan@yahoo.com).

Received: 11/03/13; accepted: 11/07/13 


\section{Introduction}

Adolescents represent nearly $18 \%$ of the world's population. Yet, despite their importance as the future generation of adults, they receive less attention to their health concerns than other age groups [1]. Adolescence is a stage of human development in which risk-taking and violent behaviours are common $[2,3]$. Almost everywhere the main victims, not only the perpetrators, of such violence are the adolescents and young adults themselves [4]. The problem of adolescent violence cannot be viewed in isolation from other problem behaviours, such as truancy and dropping out from school, substance abuse, compulsive lying and reckless driving. However, not all violent adolescents have significant problems other than their violence and not all adolescents with problems are necessarily violent [5].

Adolescent aggression and violence often emanates from multiple risk factors, including biological vulnerability; an inconsistent, overly permissive or harsh family environment; community deprivation; poor social attachment; easy access to weapons; and exposure to violence [6]. Violent behaviour rarely appears spontaneously; it typically has a long developmental pathway. In certain instances, aggression may be a response to stress that occurs during a vulnerable period of life, and an individual may not respond in the same volatile way at a different time in his/her life. However, there is usually some continuity in violence between childhood, adolescence and adult life [2]. Identification of adolescents who are exposed to multiple risk factors can help to inform interventions before the aggressive behaviour becomes chronic, frequent, pervasive and severe. Examining the primary risk factors and developmental pathways will also help to enhance understanding of aggression and to device effective interventions [2].
Adolescents in Egypt amount to nearly 20 million and hence represent a substantial proportion of the country's human potential. They are exposed to the many of the same risk factors that predispose to aggression and criminal behaviour elsewhere in the world. Exposure to violence among adolescents, particularly violence in the community, may also have increased recently due to the political instability and conflict in Egypt since 2011, as reported in the media. This exposure could be direct (being involved) or indirect (being witnesses) to violence. The aim of the current study was to identify the risk factors responsible for aggression, violence and criminal behaviour and assess the magnitude of these risks among adolescents living in Alexandria Governorate, Egypt.

\section{Methods}

\section{Study sample}

A multistage, cluster sampling technique was used to select a representative sample of families from the 8 health districts in Alexandria taking into consideration the estimated population size of these districts for the year 2010 [7]. The sample size was determined using Epi-Info, version 6. Based on the assumption that the risk of aggression is $50 \%$, precision is $5 \%$ and design effect is 2 , the calculated sample at $95 \%$ confidence level was found to be approximately 770 persons. According to census data, the average number of adolescents aged 11-19 years per family was 0.8 and therefore a total number of 1000 families were suggested to obtain the desired number of adolescents. Thirty clusters from different districts of Alexandria were selected using probability proportionate to size. Each cluster was composed of at least 35 families. The resulting sample amounted to 1031 families who were found to have 829 adolescents; detailed information was possible to collect from 783 (94.5\%) of these adolescents. The study was carried out during the second quarter of 2012

An informed consent was taken from the interviewed parent and in the case of an adolescent aged 16+ years his/her consent was also taken. The purpose of the research, confidentiality of information and benefit to the population was explained to the participants. Anonymity and confidentiality were guaranteed and maintained.

\section{Data collection}

The selected families were visited by trained interviewers who collected data about the adolescent using a predesigned interview questionnaire by interviewing the mother or, in the event she was not available for interview, collecting data from the father or in a few cases a grandparent or an older sibling.

The questionnaire consisted of 2 sections. The first section collected data about the adolescent's and the family's sociodemographic characteristics, and asked about the presence of violence and its type among the adolescent's family and the presence of cases of substance abuse among family members. The second section of the questionnaire addressed various behaviours of the adolescents including antisocial behaviours, aggression and criminal tendencies. An Arabic translation of the screening questionnaire developed by the Mentor Research Institute was used for this part of the study [8]. It consisted of 51 items; each item was given a score. The total risk score was calculated by summing scores of all items and the level of risk was classified as low (score $\leq 16$ ), moderate score 17-32), high (score 33-84) and extremely high (score $\geq 85$ ).

The validity of the English version of the Mentor Research Institute questionnaire has been reported by the original authors of the tool. For this study an Arabic translation of the questionnaire was checked by forward then backward translation by qualified interpreters. The 
questionnaire was subsequently modified and its reliability was tested through a pilot study on 20 participants. The internal consistency of the Arabic version of the scale as measured by Cronbach alpha was 0.94 . Its content validity was confirmed through an extensive literature review and through experts specialized in behavioural sciences and mental health.

\section{Data analysis}

The risk score was computed and the association between the score and covariates was assessed by univariate analysis. The 5\% level was used as the cut-off value for statistical significance. Multiple regression analysis was applied with the aggression score being the dependent variable against all other variables as independent variables.

\section{Results}

The level of risk of aggression and criminal behaviour among the studied adolescents are presented in Table 1. According to the adopted classification, $32.0 \%$ of the adolescents were at low risk, $20.9 \%$ at moderate risk, $26.9 \%$ at high risk and $20.2 \%$ at extremely high risk of aggression and of criminal behaviour.

Table 2 shows the distribution of adolescents according to some sociodemographic factors and level of risk. Those living in rural areas showed much lower risk of aggression than those living in urban or slum areas. The difference in the level of risk between areas of living was statistically significant $\left(\chi^{2}=17.67, P<0.05\right)$. Those who were in the early years of adolescence showed significantly higher rates of high and extremely high risk of aggression than those who were in the later years of adolescence $\left(\chi^{2}=18.45, P=\right.$ $0.005)$. Male adolescents had significantly much higher rates of risk for aggression than females, particularly with regard to the extremely high risk level $\left(\chi^{2}=34.01, P<0.005\right)$.

Analysing the risks according to socioeconomic standard of the family of the adolescents, it was found that the higher the level of education of the parent, the lower the rate of extremely high risk of aggression. This association was found to be statistically significant for fathers' $(P=0.001)$ and mothers' education $(P=0.02)$. Adolescents of families where fathers were professionals had significantly lower rates of being at extremely high risk of aggression (Monte Carlo $P$ $=0.005$ ). A similar picture was seen concerning mothers' occupation. Adolescents of mothers with a professional job had lower rates of extremely high risk of aggression and the reverse was seen for mothers who were doing unskilled work outside their homes, although the differences were not statistically significant. The crowding index at home was studied to see if there was an effect on the risk of aggression among adolescents. Table 2 shows that for those living with $<2$ persons/room the rate of extremely high risk of aggression was slightly lower than that among those living under more crowded conditions, but these differences were not statistically significant $\left(\chi^{2}=15.07, P=0.09\right)$.

Table 3 shows that during their lifetime, 511 of the 783 studied adolescents $(65.3 \%)$ had been exposed to or witnessed violence within their families. The risk of aggression, particularly the very high risk level, was nearly 4 times higher among adolescents who lived in families with violence at home. This difference was highly significant $(P<0.001)$. Studying the type of violence and the person targeted, the table shows that when there was violence against the mother the risk of aggression among adolescents, particularly the high risk category, increased significantly. This was the case whether the violence was physical or verbal. This increase was statistically significant $\left(\chi^{2}\right.$ $=27.39$ and 20.06 respectively, $P<$ $0.001)$. The same picture was observed when the family violence was against the brothers or sisters of the adolescent, whether it was physical or verbal. The rate of very high risk of aggression when there was violence against brothers and sisters was significantly 2-3 times higher than when there was no violence $\left(\chi^{2}=44.24\right.$ and 46.24 respectively, $P<0.001)$. The table also shows that violence against the adolescents' mothers was more often verbal than physical (4:1). This was also true for brothers and sisters but to a lesser degree $(2: 1)$.

Table 4 shows that the rates of exposure to violence at home were very similar for male and female adolescents: $276 / 419$ (65.9\%) and $235 / 364$ (64.6\%) respectively. However, the risk of aggression and violence, particularly the high and extremely high risk categories, were significantly higher among male than female adolescents.

Respondents were asked about any change in behaviour of any family member which might be manifested in the form of depression, aggression,

\begin{tabular}{lcc}
\hline $\begin{array}{l}\text { Table 1 Distribution of studied adolescents according to their risk for aggression } \\
\text { and criminal behaviour (Alexandria, 2012) }\end{array}$ & \multicolumn{2}{c}{ No } \\
\hline Risk of aggression and criminal behaviour ${ }^{\mathrm{a}}$ & 250 & 32.0 \\
Low risk (score $\leq 16)$ & 164 & 20.9 \\
Moderate risk (score 17-32) & 211 & 26.9 \\
High risk (score 33-84) & 158 & 20.2 \\
Extremely high (score $\geq 85)$ & 783 & 100.0 \\
\hline Total
\end{tabular}

${ }^{a}$ Scores on the Mentor Research Institute's screening questionnaire for youth at risk [8]. 


\begin{tabular}{|c|c|c|c|c|c|c|c|c|c|c|}
\hline \multirow[t]{2}{*}{ Variable } & \multirow{2}{*}{$\begin{array}{l}\text { Total } \\
\text { No. }\end{array}$} & \multicolumn{2}{|c|}{ Low risk } & \multicolumn{2}{|c|}{$\begin{array}{l}\text { Moderate } \\
\text { risk }\end{array}$} & \multicolumn{2}{|c|}{ High risk } & \multicolumn{2}{|c|}{$\begin{array}{l}\text { Extremely } \\
\text { high risk }\end{array}$} & \multirow[t]{2}{*}{ Test of significance } \\
\hline & & No. & $\%$ & No. & $\%$ & No. & $\%$ & No. & $\%$ & \\
\hline Total & 783 & 250 & 32.0 & 164 & 20.9 & 211 & 26.9 & 158 & 20.2 & \multirow{4}{*}{$\chi^{2}=17.67 ; \mathrm{df}=6 ; P=0.007$} \\
\hline \multicolumn{11}{|l|}{ Area of living } \\
\hline Urban & 504 & 139 & 27.6 & 116 & 23.0 & 148 & 29.4 & 101 & 20.0 & \\
\hline Rural & 152 & 65 & 42.7 & 29 & 19.1 & 29 & 19.1 & 29 & 19.1 & \\
\hline Slum & 127 & 46 & 36.2 & 19 & 15.0 & 34 & 26.8 & 28 & 22.0 & \\
\hline \multicolumn{11}{|l|}{ Age (years) } \\
\hline $11-$ & 319 & 83 & 26.0 & 63 & 19.7 & 92 & 28.8 & 81 & 25.4 & \multirow{3}{*}{$\chi^{2}=18.45 ; \mathrm{df}=6 ; P=0.05$} \\
\hline $14-$ & 285 & 102 & 35.8 & 58 & 20.4 & 82 & 28.8 & 43 & 15.1 & \\
\hline $17-19$ & 179 & 65 & 36.3 & 43 & 24.0 & 37 & 20.7 & 34 & 19.0 & \\
\hline \multicolumn{11}{|l|}{ Sex } \\
\hline Male & 419 & 109 & 26.0 & 75 & 17.9 & 124 & 29.6 & 111 & 26.5 & \multirow{2}{*}{$\chi^{2}=34.01 ; \mathrm{df}=3 ; P<0.001$} \\
\hline Female & 364 & 141 & 38.7 & 89 & 24.5 & 87 & 23.9 & 47 & 12.9 & \\
\hline \multicolumn{11}{|l|}{ Father's education $(n=746)^{a}$} \\
\hline Illiterate/just read \& write & 227 & 86 & 37.9 & 33 & 14.5 & 51 & 22.5 & 57 & 25.1 & \multirow{4}{*}{$\chi^{2}=28.24 ; \mathrm{df}=9 ; P<0.001$} \\
\hline Primary/preparatory & 103 & 34 & 33.0 & 20 & 19.4 & 23 & 22.3 & 26 & 25.2 & \\
\hline Secondary/diploma & 312 & 84 & 26.9 & 75 & 24.0 & 94 & 30.1 & 59 & 18.9 & \\
\hline University/higher & 104 & 32 & 30.8 & 30 & 28.8 & 32 & 30.8 & 10 & 9.6 & \\
\hline \multicolumn{11}{|l|}{ Mother's education $(n=776)^{a}$} \\
\hline Illiterate/just read \& write & 331 & 108 & 32.6 & 61 & 18.4 & 81 & 24.5 & 81 & 24.5 & \multirow{4}{*}{$\chi^{2}=20.51 ; \mathrm{df}=9 ; P=0.02$} \\
\hline Primary/preparatory & 101 & 29 & 28.7 & 28 & 27.7 & 19 & 18.8 & 25 & 24.8 & \\
\hline Secondary/diploma & 275 & 85 & 33.3 & 56 & 26.1 & 89 & 32.4 & 45 & 16.4 & \\
\hline University/higher & 69 & 23 & 31.6 & 18 & 21.0 & 21 & 27.1 & 7 & 10.1 & \\
\hline \multicolumn{11}{|l|}{ Father's occupation $(n=746)^{a}$} \\
\hline Unskilled & 176 & 61 & 34.7 & 37 & 21.0 & 41 & 23.3 & 37 & 21.0 & \multirow{7}{*}{ MC $P<0.001$} \\
\hline Skilled & 154 & 54 & 35.1 & 23 & 14.9 & 45 & 29.2 & 32 & 20.8 & \\
\hline Clerical & 117 & 29 & 24.8 & 31 & 26.5 & 30 & 25.6 & 27 & 23.1 & \\
\hline Commerce & 111 & 22 & 19.8 & 22 & 19.8 & 41 & 36.9 & 26 & 23.4 & \\
\hline Professional & 104 & 31 & 29.8 & 33 & 31.7 & 29 & 27.9 & 11 & 10.6 & \\
\hline Retired & 60 & 29 & 48.3 & 10 & 16.7 & 7 & 11.7 & 14 & 23.3 & \\
\hline Other & 24 & 10 & 41.7 & 2 & 8.3 & 7 & 29.2 & 5 & 20.8 & \\
\hline \multicolumn{11}{|l|}{ Mother's occupation $(n=776)^{a}$} \\
\hline Housewife & 576 & 192 & 33.3 & 121 & 21.0 & 141 & 24.5 & 122 & 21.2 & \multirow{4}{*}{ MC $P<0.001$} \\
\hline Professional & 80 & 29 & 36.2 & 12 & 15.0 & 28 & 35.0 & 11 & 13.8 & \\
\hline Clerical & 79 & 16 & 20.3 & 21 & 26.6 & 28 & 35.4 & 14 & 17.7 & \\
\hline Unskilled & 41 & 8 & 19.5 & 9 & 22.0 & 13 & 31.7 & 11 & 26.8 & \\
\hline \multicolumn{11}{|l|}{ Crowding index (persons/room) } \\
\hline$<2$ & 387 & 131 & 33.9 & 68 & 17.6 & 116 & 30.0 & 72 & 18.6 & \multirow{3}{*}{$\chi^{2}=8.70 ; \mathrm{df}=6 ; P=0.191$} \\
\hline $2-$ & 313 & 95 & 30.4 & 76 & 24.3 & 74 & 23.6 & 68 & 21.7 & \\
\hline $3+$ & 83 & 24 & 28.9 & 20 & 24.1 & 21 & 25.3 & 18 & 21.7 & \\
\hline
\end{tabular}

${ }^{a}$ Excluding those who were dead.

$d f=$ degrees of freedom; $M C=$ Monte Carlo. 


\begin{tabular}{|c|c|c|c|c|c|c|c|c|c|c|}
\hline \multirow[t]{2}{*}{ Variable } & \multirow{2}{*}{$\begin{array}{l}\text { Total } \\
\text { No. }\end{array}$} & \multicolumn{2}{|c|}{ Low risk } & \multicolumn{2}{|c|}{ Moderate risk } & \multicolumn{2}{|c|}{ High risk } & \multicolumn{2}{|c|}{$\begin{array}{l}\text { Extremely } \\
\text { high risk }\end{array}$} & \multirow[t]{2}{*}{ Statistics } \\
\hline & & No. & $\%$ & No. & $\%$ & No. & $\%$ & No. & $\%$ & \\
\hline Total & 783 & 250 & 32.0 & 164 & 20.9 & 211 & 26.9 & 158 & 20.2 & \\
\hline \multicolumn{11}{|c|}{ Violence in the family } \\
\hline Violence & 511 & 138 & 27.0 & 99 & 19.4 & 136 & 26.6 & 138 & 27.0 & \multirow{2}{*}{$\chi^{2}=46.94 ; \mathrm{df}=3 ; P<0.001$} \\
\hline No violence & 272 & 112 & 41.2 & 65 & 23.9 & 75 & 27.6 & 20 & 7.4 & \\
\hline \multicolumn{11}{|c|}{ Violence against mother } \\
\hline \multicolumn{11}{|l|}{ Physical } \\
\hline Yes & 111 & 20 & 18.0 & 18 & 16.2 & 32 & 28.8 & 41 & 36.9 & \multirow[t]{2}{*}{$\chi^{2}=27.39 ; \mathrm{df}=3 ; P<0.001$} \\
\hline No & 672 & 230 & 34.2 & 146 & 21.7 & 179 & 26.6 & 117 & 17.4 & \\
\hline \multicolumn{11}{|l|}{ Verbal } \\
\hline Yes & 430 & 121 & 28.1 & 88 & 20.5 & 110 & 25.6 & 111 & 25.8 & \multirow[t]{2}{*}{$\chi^{2}=20.06 ; \mathrm{df}=3 ; P<0.001$} \\
\hline No & 353 & 129 & 36.5 & 76 & 21.5 & 101 & 28.6 & 47 & 13.3 & \\
\hline \multicolumn{11}{|c|}{$\begin{array}{l}\text { Violence against brothers } \\
\text { or sisters }\end{array}$} \\
\hline \multicolumn{11}{|l|}{ Physical } \\
\hline Yes & 172 & 42 & 24.4 & 23 & 13.4 & 42 & 24.4 & 65 & 37.8 & \multirow[t]{2}{*}{$\chi^{2}=44.24 ; \mathrm{df}=3 ; P<0.001$} \\
\hline No & 611 & 208 & 34.0 & 141 & 23.1 & 169 & 27.7 & 93 & 15.2 & \\
\hline \multicolumn{11}{|l|}{ Verbal } \\
\hline Yes & 388 & 99 & 28.5 & 72 & 18.6 & 102 & 26.3 & 115 & 29.6 & \multirow[t]{2}{*}{$\chi^{2}=46.24 ; \mathrm{df}=3 ; P<0.001$} \\
\hline No & 395 & 151 & 38.2 & 92 & 23.3 & 109 & 27.6 & 43 & 10.9 & \\
\hline
\end{tabular}

$d f=$ degrees offreedom .

criminal tendency or withdrawal from the community. Table 5 shows that in the risk of aggression among adolescents, especially the extremely high risk category, increased significantly with reported behavioural changes in any family member (Monte Carlo $P$ $<0.001$ ). The same was also observed when any member of the family was a substance abuser (cannabis, heroin, prescription medications, alcohol or others $)(P<0.001)$.

Table 6 presents the results of the multivariate analysis of the relationship between the independent variables and the risk of aggression among adolescents. It shows that the sex of the adolescent and the presence of behavioural changes within the family were the most significant independent variables, followed by violence against the brothers and sisters of the adolescent and substance abuse by any member in the family.

\begin{tabular}{|c|c|c|c|c|c|c|c|c|c|c|}
\hline \multirow[t]{2}{*}{$\begin{array}{l}\text { Sex/Exposure to } \\
\text { violence in family }\end{array}$} & \multirow{2}{*}{$\begin{array}{l}\text { Total } \\
\text { No. }\end{array}$} & \multicolumn{2}{|c|}{ Low risk } & \multicolumn{2}{|c|}{ Moderate risk } & \multicolumn{2}{|c|}{ High risk } & \multicolumn{2}{|c|}{$\begin{array}{l}\text { Extremely high } \\
\text { risk }\end{array}$} & \multirow[t]{2}{*}{ Statistics } \\
\hline & & No. & $\%$ & No. & $\%$ & No. & $\%$ & No. & $\%$ & \\
\hline \multicolumn{11}{|l|}{ Male } \\
\hline Exposed & 276 & 61 & 22.1 & 38 & 13.8 & 78 & 28.3 & 99 & 35.9 & \multirow{3}{*}{$\chi^{2}=39.8 ; \mathrm{df}=3 ; P<0.001$} \\
\hline Not exposed & 143 & 48 & 33.6 & 37 & 26.0 & 46 & 24.7 & 12 & 16.6 & \\
\hline Total & 419 & 109 & 26.0 & 75 & 17.9 & 124 & 29.6 & 111 & 26.5 & \\
\hline \multicolumn{11}{|l|}{ Female } \\
\hline Exposed & 235 & 77 & 32.8 & 61 & 26.0 & 58 & 24.7 & 39 & 16.6 & \multirow{3}{*}{$\chi^{2}=13.9 ; \mathrm{df}=3 ; P=0.003$} \\
\hline Not exposed & 129 & 64 & 49.6 & 28 & 21.7 & 29 & 22.5 & 8 & 6.2 & \\
\hline Total & 364 & 141 & 38.7 & 89 & 24.5 & 87 & 23.9 & 47 & 12.9 & \\
\hline
\end{tabular}

$d f=$ degrees of freedom. 


\begin{tabular}{|c|c|c|c|c|c|c|c|c|c|c|}
\hline \multirow[t]{2}{*}{ Variable } & \multirow{2}{*}{$\begin{array}{l}\text { Total } \\
\text { No. }\end{array}$} & \multicolumn{2}{|c|}{ Low risk } & \multicolumn{2}{|c|}{ Moderate risk } & \multicolumn{2}{|c|}{ High risk } & \multicolumn{2}{|c|}{$\begin{array}{c}\text { Extremely high } \\
\text { risk }\end{array}$} & \multirow[t]{2}{*}{ Statistics } \\
\hline & & No. & $\%$ & No. & $\%$ & No. & $\%$ & No. & $\%$ & \\
\hline Total & 783 & 250 & 32.0 & 164 & 20.9 & 211 & 26.9 & 158 & 20.2 & \\
\hline \multicolumn{11}{|c|}{ Behavioural changes } \\
\hline Yes & 169 & 36 & 21.3 & 22 & 13.0 & 50 & 29.6 & 61 & 36.1 & $\chi^{2}=41.70 ; \mathrm{df}=3 ; P<0.001$ \\
\hline No & 614 & 214 & 34.8 & 142 & 23.1 & 161 & 26.2 & 97 & 15.8 & \\
\hline \multicolumn{11}{|c|}{ Substance abuse } \\
\hline Yes & 127 & 25 & 19.7 & 35 & 27.6 & 31 & 24.4 & 36 & 28.3 & $\chi^{2}=15.66 ; \mathrm{df}=3 ; P=0.001$ \\
\hline No & 656 & 225 & 34.3 & 129 & 19.7 & 180 & 27.4 & 122 & 18.6 & \\
\hline
\end{tabular}

$d f=$ degrees offreedom.

\section{Discussion}

Children and adolescents continue to be exposed to several risk factors that can harm their development and contribute to problem behaviours. While many children and adolescents surmount individual risk factors, those who endure several risks simultaneously are more likely to develop serious behavioural problems [9].

This study has shown that 1 in every 5 of the studied adolescents was at extremely high risk of aggression and criminal behaviour and another quarter was at high risk. Although these are high rates it is likely that they are underestimates because they rely on mothers' reporting of incidents, some of which may be undisclosed or minimized.

In this study, a significantly lower risk of aggression and criminal behaviour was found among adolescents who lived in rural than in urban areas. Rural neighbourhoods and their sociodemographic characteristics are much less conducive to violence than the urban environment. On the other hand, the prevailing conditions in slums are expected to increase the risk of aggression [10]. In this study, adolescents living in slums an urban areas were found to greater high risk and very high risk rates than those living in rural areas. The fact that many of the families living in slum areas in Alexandria are originally from rural areas, and migrated to urban areas in search of a better life, may explain the reason that their risk was not higher than those living in urban areas.

The risk rates for aggression were found to be much higher among young adolescents (11-14 years) than those in the older age groups. The reason for this requires further study but we hypothesize that it could be attributed to the fact that exposure to violence, which could include hearing about, being told about or seeing evidence of it in the community, has increased in Egypt during the last 2 years, since the political events of 2011. This means that these young adolescents have accumulated more experiences in the last few years than those who are older. It also suggests that as adolescents approach maturity, some of the youthful behaviours or conduct problems tend to disappear [10]. In general, however, the risk for aggression and violent behaviours might show an increase if no measures are taken to address the situation by the relevant authorities.

The impact of sociodemographic characteristics of the families on the risk of aggression among adolescents was evidenced by the negative correlation between the level of education and occupation of parents and the risk of

\begin{tabular}{|c|c|c|c|}
\hline Independent variable & $\begin{array}{c}\text { Standardized } \\
\text { coefficient (beta) }\end{array}$ & $t$-value & $P$-value \\
\hline Behavioural changes in family member & 0.211 & 5.43 & $<0.001$ \\
\hline Sex of the adolescent & 0.217 & 6.51 & $<0.001$ \\
\hline Verbal violence against brothers/sisters & 0.137 & 3.95 & $<0.001$ \\
\hline Substance abuse by family member & 0.098 & 2.84 & 0.005 \\
\hline Physical violence against spouse & 0.090 & 2.37 & 0.018 \\
\hline
\end{tabular}

Dependent variable was total risk score of the adolescent. 
aggression in adolescents, particularly the high and extremely high categories. Similar results were reported from other studies $[11,12]$.

It is known that experience of violence can lead to harm, which may turn lead to aggression and conduct problems $[13,14]$. It is also known that children and adolescents who are exposed to real or perceived threats may become conditioned to react with anxiety to a broad range of circumstances and became perpetrators of violence [13]. In this study, where it was possible only to assess exposure to violence within the families either directly (as victims) or indirectly (as witnesses to violence against another family member), it was found that two-thirds of the adolescents had been exposed to violence within their families. A very similar rate of exposure was reported from the United States in 2008 in a comprehensive national survey [15].

The observed higher risk rates of aggression and criminal behaviour among male than female adolescents were similar to reports from other countries $[15,16]$. This is probably due to the greater exposure of males to violence than females. In this study, exposure to violence at home was similar between male and female adolescents. However, witnessing or involvement in violence in the community is more likely to occur with male than female adolescents, which could partly explain the higher risk rates of aggression in males, especially in the Egyptian community where it is accepted that males express aggression more than females. Although the linkage between various independent variables was clear, multiple regression analysis highlighted that the presence of behavioural changes in the family, aggression against the children, and substance abuse by any family member were the most significant factors affecting the risk of aggression among adolescents. These results underline the importance of working with families in which aggression is reported in order to reduce the risk to the adolescent family members. Similar studies have also come to the same conclusion [17]. Schools and media can also play a major role in stress coping among children and youth in several ways such as for example by promoting positive role models. They can also play important roles with the families to reduce the factors that have been shown to increase the risk of aggression and criminal behaviour among adolescents [18].

\section{Conclusions}

This study highlighted the high risks of aggression and criminal behaviour among adolescents in Alexandria It has shown the role played by several factors in this regard. It is sincerely hoped that the responsible authorities and agencies begin to take necessary measures to reduce the negative impacts of exposure to violence through giving special attention to changing the perception of children and adolescents to these risks.

\section{Acknowledgements}

Competing interests: None declared.

\section{References}

1. The state of the world's children 2011. Adolescence: an age of opportunity. New York, United Nations Children's Fund, 2011:138.

2. Marcus RF. Aggression and violence in adolescence, 1st ed. Cambridge, Cambridge University Press, 2007.

3. Rappaport N, Thomas C. Recent research findings on aggressive and violent behavior in youth: implications for clinical assessment and intervention. Journal of Adolescent Health, 2004, 35:260-277.

4. Reza A, Mercy JA, Krug E. Epidemiology of violent deaths in the world. Injury Prevention, 2001, 7:104-111.

5. Youth violence. A report of the Surgeon General. Washington DC, United States Department of Health and Human Services, 2001.

6. Cortazar RZ. Adolescent criminal behavior partly a matter of choice. Refraining from or engaging in violence not just a matter of poverty and community. Boston, Massachusetts, Harvard Gazette Archives, 2006.

7. Information and decision making center. The annual statistical report for the year 2010. Alexandria, Egypt, Ministry of Health and Population, 2011:206.

8. Youth at risk screening questionnaire. Portland, Oregon, Mentor Research Institute, 1998 [Internet] (http://behavioralinstitute.
org/uploads/Youth_At_Risk_Screening_Questionnaire.pdf, accessed 25 February 2014).

9. Garmezy N. Children in poverty: resilience despite risk. Psychiatry, 1993, 56:127-136.

10. Resolution 45/112. United Nations Guidelines for the Prevention of Juvenile Delinquency (the Riyadh Guidelines). Adopted at the Sixty-eighth Plenary Meeting of the General Assembly, 14 December 1990. New York, United Nations, 1990 (A/RES/45/112) (http://www.un.org/documents/ga/res/45/a45r112.htm, accessed 18 December 2013).

11. Evans GW. The environment of childhood poverty. American Psychologist, 2004, 59:77-92.

12. Moore KA, Vandivere S, Ehrle J. National survey of the American families. Sociodemographic risk and child well being. Washington DC, The Urban Institute, 2000:B-18.

13. Margolin G, Elana BG. Children exposure to violence in the family and community. Current Directions in Psychological Science, 2004, 13:152-155.

14. Duke NN et al. Adolescent violence perpetration: associations with multiple types of adverse childhood experiences. Pediatrics, 2010, 125:e778-e786.

15. Finkelhor D et al. Violence, abuse, and crime exposure in a national sample of children and youth. Pediatrics, 2009, 124:1411-1423. 
16. Fagan AA, Wright EM. The effect of neighborhood context on youth violence and delinquency. Does gender matter? Youth Violence and Juvenile Justice, 2012, 10:64-82.

17. Andreas JB, Watson MW. Moderating effects of family environment on the association between children's aggres- sive beliefs and their aggression trajectories from childhood to adolescence. Development and Psychopathology, 2009, 21:189-205.

18. Lopez EE et al. Adolescent aggression: effects of gender and family and school environments. Journal of Adolescence, 2008, 31:433-450. 